\title{
AGRONOMIC PERFORMANCE OF GRAIN SORGHUM CULTIVATED IN DOUBLE ROWS SPACE ON BRAZILIAN CERRADO ${ }^{1}$
}

\author{
EDUARDO LIMA DO CARMO ${ }^{2}$, JOÃO VITOR ALVES DE SOUSA ${ }^{3}$, CAMILA JORGE BERNABÉ FERREIRA*3*, \\ GUILHERME BRAGA PEREIRA BRAZ ${ }^{2}$, GUSTAVO ANDRÉ SIMON²
}

\begin{abstract}
The spatial arrangement of plants in the cultivation area is a factor that directly influences grain yield, since the best arrangement can result in the greater use of water, light and nutrients. The aim of the study was to evaluate the agronomic performance of sorghum sown in double row spacing in the Brazilian Cerrado. For this purpose, field experiments were conducted in the 2018 and 2019 seasons in a complete block design with a factorial scheme of $2 \times 5$. There were four replications, using two row spacing: traditional $(0.50 \mathrm{~m})$ and double rows $(0.25 \mathrm{~m} / 0.75 \mathrm{~m})$ and five plant populations: 120,180 (recommended), 240, 300 and 360 thousand, plants $\mathrm{ha}^{-1}$. Morphological characteristics, yield components and grain yield were evaluated using joint data analysis for the two years of study. In 2018, due to lower rainfall during the crop season, the use of a double row arrangement presented grain yield lower than traditional spacing. On the other hand, in 2019, the year with the best water distribution, the yield was superior to that of 2018. The increase in plant population per hectare increased the yield of sorghum grains, with gains of up to $24 \%$ in relation to the recommended population of 180 thousand plants $\mathrm{ha}^{-1}$, demonstrated that the densification in this crop can be a promising technique as long as its cost/benefit is considered.
\end{abstract}

Keywords: Second crop season. Inter-row spacing. Sowing density. Sorghum bicolor.

\section{DESEMPENHO AGRONÔMICO DO SORGO GRANÍFERO CULTIVADO EM ESPAÇAMENTO DE FILEIRAS DUPLAS NO CERRADO}

\begin{abstract}
RESUMO - A disposição espacial em que plantas se encontram na área de cultivo é fator que influencia diretamente na produtividade de grãos, pois o melhor arranjo entre essas pode resultar em maior aproveitamento de água, luz e nutrientes. O objetivo do trabalho foi avaliar o desempenho agronômico de sorgo semeado em espaçamento de fileiras duplas no Cerrado. Para tanto, foi conduzido nas safrinhas de 2018 e 2019, experimentos de campo em delineamento de blocos completos em esquema fatorial 2 x 5 , com quatro repetições, em que se utilizou dois espaçamentos de entrelinhas de semeadura: tradicional $(0,50 \mathrm{~m})$ e fileiras duplas $(0,25 \mathrm{~m} / 0,75 \mathrm{~m})$ e cinco populações de plantas: 120, 180 (recomendada), 240, 300 e 360 mil plantas $\mathrm{ha}^{-1}$. Foram avaliadas características morfológicas, componentes do rendimento e produtividade de grãos utilizando análise conjunta dos dados para os dois anos de estudo. Em 2018, devido ao menor volume de chuvas durante o ciclo da cultura, a utilização do arranjo em fileiras duplas apresentou produtividade de grãos inferior ao espaçamento tradicional. Por outro lado, em 2019, ano com melhor distribuição hídrica, a produtividade foi superior a 2018. O aumento da população de plantas por hectare incrementou a produtividade de grãos de sorgo, com ganhos de até $24 \%$ em relação à população recomendada de 180 mil plantas ha $^{-1}$, demonstrando que o adensamento nessa cultura pode ser uma técnica promissora desde que levado em consideração seu custo/benefício.
\end{abstract}

Palavras-chave: Cultivo de safrinha. Espaçamento entrelinhas. População de plantas. Sorghum bicolor.

\footnotetext{
*Corresponding author

${ }^{1}$ Received for publication in $10 / 30 / 2019$; accepted in $01 / 27 / 2020$.

Paper extracted from the researcher scholarship of the first author.

${ }^{2}$ Departament of Agronomy, Universidade de Rio Verde, Rio Verde, GO, Brazil; eduardo@unirv.edu.br - ORCID: 0000-0001-8023-5245, guilhermebrag@gmail.com - ORCID: 0000-0002-0396-7140, simon@unirv.edu.br - ORCID: 0000-0001-6935-6580.

${ }^{3}$ Graduate Program in Plant Production, Universidade de Rio Verde, Rio Verde, GO, Brazil; joaovitor.alves@gapescna.agr.br - ORCID: 0000-0002-9766-1395, camilajbferreira@gmail.com - ORCID: 0000-0001-5006-9661.
} 


\section{INTRODUCTION}

The great need for grain in the world, associated with the advance of increasing sorghum hybrids in the market with satisfactory yields, has been driving the increase in cultivated areas with this cereal in Brazil each year. It is noteworthy that the state of Goiás is the largest producer of sorghum in the country, which represents more than $40 \%$ of the production of this crop (IBGE, 2019).

Sorghum is considered an interesting alternative for second crop (safrinha) cultivation in the Cerrado region, and can be used as an energy source for human and animal food, especially with similar nutritional value to corn (BENEDETTI et al., 2015). The main advantages of sorghum compared to the cultivation of corn is that this crop has greater drought tolerance (typical conditions of the Brazilian Cerrado) and lower production costs (BUFFARA et al., 2018).

Despite the growing demand for sorghum cultivation in the country, there are still many doubts regarding phytotechnical adjustments to ensure greater crop yield. To increase sorghum grain yield it is necessary to define, among other techniques, the ideal plant arrangement. In this way, solar radiation, soil nutrients and water will be more efficiently exploited by the crop (ALBUQUERQUE et al., 2010; ALMEIDA et al., 2000). Research results concluded that the crop is highly influenced by environmental conditions (BAUMHARDT; HOWELL, 2006) and is more efficient than corn and wheat in converting water into dry matter, as it has important biochemical and morphological mechanisms which give it drought tolerance (MAGALHÃES et al., 2000).

The arrangement of plants determines the vegetation cover; that is, higher densities of plants and smaller spacing between rows increase the interception of radiation, causing the closure of rows between crops to occur at an earlier stage (PINHO; VASCONCELOS, 2002). The ideal sowing densities for sorghum cultivation may vary depending on the variety sown, the spacing between rows and the climatic conditions prevailing in that agricultural year (AVELINO et al., 2011).

In studies in which the sorghum grain sown in different plant arrangements with smaller spacing and higher densities was evaluated, grain yield increases were observed (ALBUQUERQUE et al., 2011). Contradicting these results, Braz et al. (2019) did not prove any influence of plant population and inter-row spacing on grain yield, although they did observe a reduction in weed density and dry weed mass.

In this sense, the need arises to evaluate different spatial arrangements of plants in order to cover the production of sorghum in the Cerrado region, aiming at greater use and benefits for the crop. Thus, this study aimed to evaluate the agronomic performance of sorghum sown in different spatial arrangements of plants in the Cerrado.

\section{MATERIAL AND METHODS}

The study was conducted in the off-season of 2018 and 2019 in an experimental area of the University of Rio Verde, located in the municipality of Rio Verde (GO), with the geographical coordinates $17^{\circ} 47^{\prime} 03.9^{\prime \prime} \mathrm{S} 50^{\circ} 57^{\prime} 51.8^{\prime \prime} \mathrm{W}$. The soil in the area was identified as a Latossolo Vermelho Distroférrico (SANTOS et al., 2018).

According to the Köppen classification, the climate of the municipality in which the experiments were conducted is tropical with a dry season, characterized by having more intense rains in the summer than in the winter (WEATHERBASE, 2019). The climatic data related to the average temperature of the air and the precipitation during the period of the experiments are presented in (Figure 1).

Before the installation of the experiments in 2018, soil samples were collected (0-20 cm layer) from the experimental area and the physical and chemical characteristics of the soil were: $\mathrm{pH}$ in $\mathrm{CaCl}_{2}=5.23 ; \mathrm{MO}=16.4 \mathrm{~g} \mathrm{~kg}^{-1} ; \mathrm{P}($ Mehlich $)=2.47$ $\mathrm{mg} \mathrm{dm}{ }^{-3} ; \mathrm{K}=0.25 \mathrm{cmolc}$ and $\mathrm{dm}^{-3} ; \mathrm{Ca}=3.03 \mathrm{cmolc}$ and $\mathrm{dm}^{-3} ; \mathrm{Mg}=1.05$ cmolc and $\mathrm{dm}^{-3} ; \mathrm{Al}=0.05$ cmolc and $\mathrm{dm}^{-3} ; \mathrm{H}+\mathrm{Al}=5.6 \mathrm{cmolc}$ and $\mathrm{dm}^{-3} ; \mathrm{CTC}=$ 9.94 cmolc and $\mathrm{dm}^{-3} ; \mathrm{V}=43.55 \% ; \mathrm{m}=1.14 \% ; \mathrm{Fe}=$ $112.4 \mathrm{cmolc}$ and $\mathrm{dm}^{-3} ; \mathrm{Mn}=109.8 \mathrm{cmolc}$ and $\mathrm{dm}^{-3}$; $\mathrm{Cu}=6.3 \mathrm{cmolc}$ and $\mathrm{dm}^{-3} ; \mathrm{Zn}=1.05 \mathrm{cmolc}$ and $\mathrm{dm}^{-3}$; clay $=580 \mathrm{~g} \mathrm{~kg}^{-1}$; silt $=80 \mathrm{~g} \mathrm{~kg}^{-1}$; and sand $=340 \mathrm{~g}$ $\mathrm{kg}^{-1}$.

The experiment was carried out in a complete randomized block design in a 2 x 5 factorial scheme, with four replications, in which the first factor was comprised of the spacing between rows of traditional sorghum $(0.50 \mathrm{~m})$ and double rows $(0.25 \mathrm{~m} / 0.75 \mathrm{~m})$ and the second of the plant population: 120,180 (recommended by the company that owns the material), 240, 300 and 360 thousand plants per hectare.

The grain sorghum used in both harvests was Dow $1 \mathrm{G} 245$ with early cycle and light brown grains. The plots were $5 \mathrm{~m}$ long by $2.5 \mathrm{~m}$ wide, with a total of $12.5 \mathrm{~m}^{2}$ of total area and a central useful area of 3 $\mathrm{m}^{2}$.

Sowing was carried out on March 4, 2018 and February 5, 2019. For both years of the study, the sowing operation was carried out using a 5-row seeder-fertilizer machine, spaced $0.50 \mathrm{~m}$ apart, equipped with furrow-type furrowers for fertilization and eccentric disks for sowing, since two sowing actions were carried out in the plots with double rows. The fertilization was the same in both years, with $85 \mathrm{~kg}$ of $\mathrm{P}_{2} \mathrm{O}_{5}$ (monoammonium phosphate) was applied in the sowing, with a coverage of $40 \mathrm{~kg} \mathrm{ha}^{-1}$ 
of $\mathrm{K}_{2} \mathrm{O}$ (potassium chloride) and $80 \mathrm{~kg}$ of $\mathrm{N}$ (urea) in flight, 15 days after sowing, when the sorghum plants were in the phenological stage V3 (three leaves fully expanded). Ten days after emergence, manual thinning was carried out, precisely establishing the desired populations.

Cultural treatments related to the control of weeds, pests and diseases were carried out by land application at a rate of $150 \mathrm{~L} \mathrm{ha}^{-1}$, respecting the minimum climatic conditions of operation: wind speed between 3 and $10 \mathrm{~km} \mathrm{~h}^{-1}$, relative humidity above $55 \%$ and ambient temperature below $30^{\circ} \mathrm{C}$, measured using a portable thermo-hygroanemometer device at the time of application at a distance of $0.5 \mathrm{~m}$ from the crop.

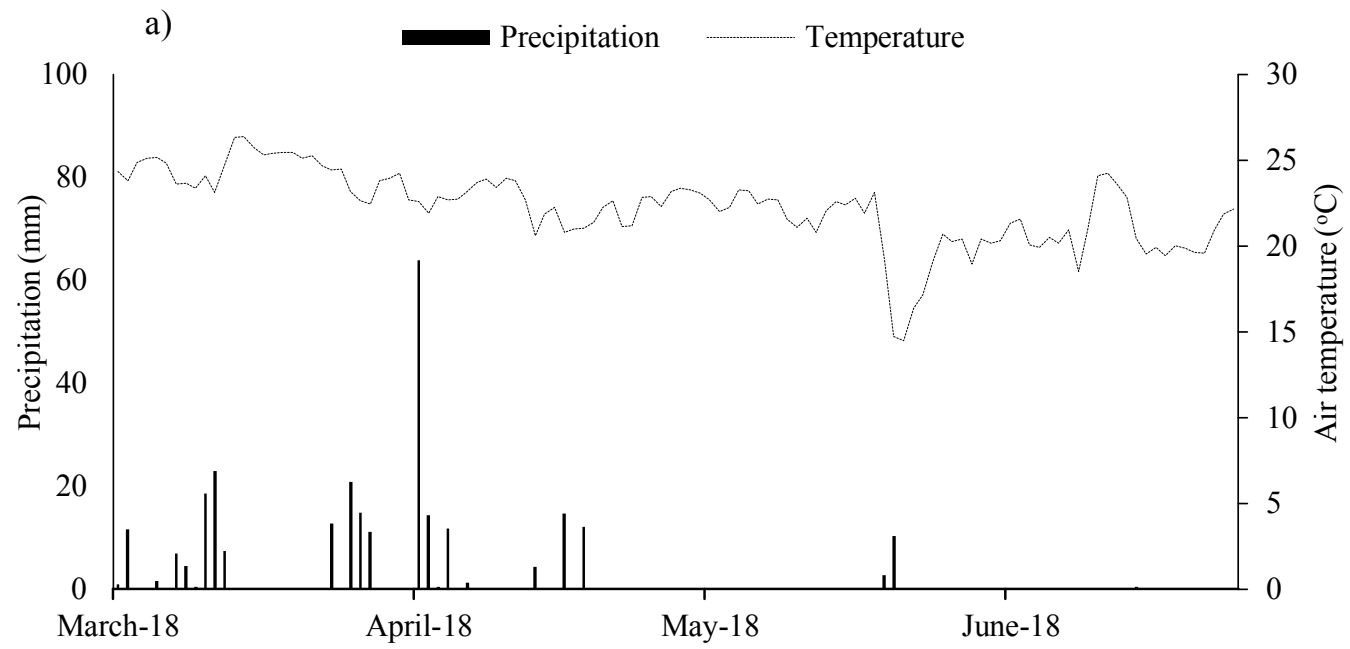

b)

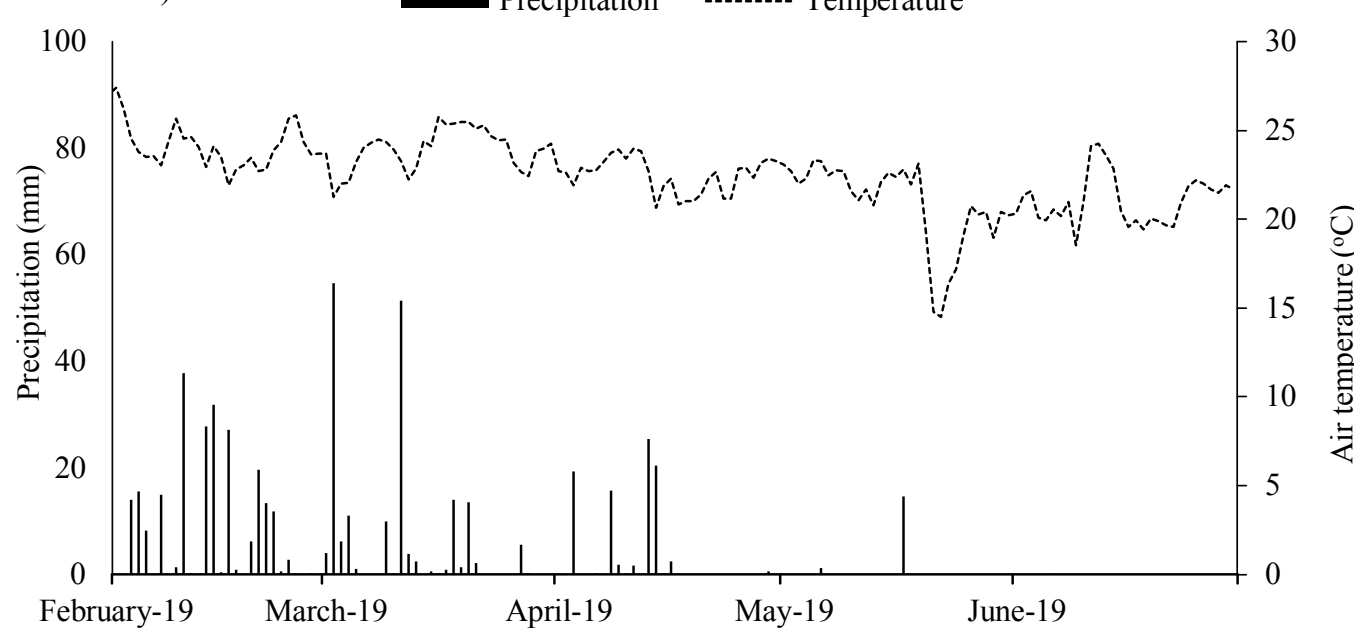

Figure 1. Precipitation and average air temperature during the period of the experiments with sorghum grown as a second crop. Rio Verde (GO), 2018 and 2019. Source: Climatological Station of the University of Rio Verde.

At harvest, the following morphological characteristics and yield components were evaluated: plant height (measurement from the neck to the end of the panicle), stem diameter (using a caliper measuring the base of the plant), mass and length measured in 10 continuous plants per plot. In addition, the number of tillers was evaluated. Grain yield was determined by harvesting panicles from the useful area of the plots with subsequent threshing and weighing of the grains, with humidity corrected to $13 \%$, converting the data to $\mathrm{kg} \mathrm{ha}^{-1}$ and, finally, the mass of a thousand grains, also corrected for $13 \%$ humidity.
The statistical analysis of the experiments was performed with the aid of the SISVAR software (FERREIRA, 2011). Joint analysis of the experiments conducted for the 2018 and 2019 harvests was performed. The data were subjected to analysis of variance by the $\mathrm{F}$ test $(\mathrm{p} \leq 0.05)$ and when a significant effect was found between the factors, or between the levels of each factor, the averages of qualitative factors (year and spatial arrangement) were compared using the $\mathrm{F}$ test $(\mathrm{p} \leq 0.05)$; for the quantitative factor (population), regression analysis $(\mathrm{p} \leq 0.05)$ was used. 


\section{RESULTS AND DISCUSSION}

In order to compare the results obtained in the experiments conducted in the two agricultural harvests, a joint analysis was performed, verifying a different effect between the response variables analyzed; for some of these, a different effect was observed depending on the year in which the experiment was conducted. An important point to be highlighted relates to the fact that, when the interaction was composed of the largest number of factors, the results of the interaction were presented. This is because it would not be interesting, from an agronomic standpoint, to present the behavior of the analyzed variable for the isolated factor in these situations. A significant triple interaction between the year of conducting the experiment, leading spacing and sorghum plant population was only observed for the plant height and thousand grain mass variables (Table 1).

Table 1. Summary of analysis of variance for the characteristics: plant height (PH), stem thickness (ST), number of tillers (NT), panicle length (PL), panicle mass (PM), mass of thousand grains (MTG) and grain yield (GY) of sorghum grown in second crop in different spatial arrangements of plants.

\begin{tabular}{lcccccccc}
\hline \multirow{2}{*}{ FV } & \multirow{2}{*}{ GL } & \multicolumn{7}{c}{ Medium square } \\
\cline { 3 - 8 } & & PH & ST & NT & PL & PM & MTG & GY \\
\hline Year (Y) & 1 & $0.558^{* *}$ & $263.8^{* *}$ & $57.8^{* *}$ & $41.185^{* *}$ & $1152.8^{* *}$ & $675.76^{* *}$ & $30751280.6^{* *}$ \\
Spacing (S) & 1 & $0.010^{*}$ & 0.5 & 0.200 & 0.098 & 11.920 & 2.454 & $1537800.43^{* *}$ \\
Population(P) & 4 & $0.008^{* *}$ & $41.2^{* *}$ & $3.425^{*}$ & $25.581^{* *}$ & $1641.184^{* *}$ & $8.594^{* *}$ & $5402420.97^{* *}$ \\
Y x S & 1 & 0.002 & 3.6 & 0.800 & 5.202 & $288.19^{* *}$ & $10.768^{* *}$ & $12456780.1^{*}$ \\
Y x P & 4 & 0.001 & 4.3 & $3.050^{* *}$ & 0.135 & $115.46^{*}$ & $4.485^{* *}$ & 832996.23 \\
S x P & 4 & 0.003 & 0.5 & 0.388 & 1.026 & 25.1693 & $4.678^{* *}$ & $1217151.39^{*}$ \\
Y x S x P & 4 & $0.006^{*}$ & 1.3 & 0.613 & 0.412 & 91.46 & $4.069^{* *}$ & 476655.39 \\
Error & 54 & 0.002 & 1.7 & 0.987 & 1.925 & 43.128 & 0.961 & 395291.33 \\
\hline CV (\%) & & 3.4 & 9.6 & 110.4 & 4.9 & 15.3 & 4.7 & 11.9 \\
\hline
\end{tabular}

$*$,**: Significant by the $\mathrm{F}$ test at 5 and $1 \%$, respectively.

For the double interactions between the factors studied, a significant effect was observed between the year of testing and the leading spacing for panicle mass and yield in contrast, for year of testing and plant population, an influence on the number of tillers and mass of panicles was verified. Finally, an effect of the interaction between leading spacing and plant population was observed only for the sorghum grain yield. Regarding the isolated factors, a significant effect was observed for the years of conducting the experiments and for the plant population on the stalk thickness and panicle length variables.

Table 2 presents the results of the evaluations of plant height, stem thickness, number of tillers and panicle length depending on the use of the two spatial arrangements, traditional and double row, making the comparison of each population of sorghum plants in the two experiments. For the plant height variable, an effect was seen only in the experiment conducted in conditions of the second crop of 2018, in which plants with greater height were found in sorghum cultivated in double rows compared to the traditional arrangement for the population of 240 thousand plants $\mathrm{ha}^{-1}$ and the average of all populations.

The stem thickness has a high negative correlation with the lodging index, since plants with a smaller stem diameter tend to be more susceptible to suffer from this process, and this behavior is verified for different crops, such as wheat, white oats and sorghum saccharine (PENCKOWSKI et al., 2009; FERNANDES et al., 2014; KASPARY et al., 2015). Comparing the spatial arrangements used for sowing sorghum in different plant populations, no differences in stem thickness were observed in either experiment.

Changes in the spatial arrangement of plants can influence the capacity of tillering of sorghum, showing that there is a reduction in the number of tillers emitted in denser spacing or higher populations. It is important to highlight that for sorghum, unlike corn, tillering is one of the forms of crop compensation due to the smaller population of plants aiming at maintaining the productive potential of the species (ALBUQUERQUE et al., 2011). In the present work, in both harvests, there was no effect of the spatial arrangements of plants on the capacity of tillering of the sorghum, regardless of the plant population used.

The length of sorghum panicles was not affected by the two spatial arrangements of plants evaluated in the experiments, with differences found only for panicle mass (Table 3 ). In the experiment conducted in 2018, a greater panicle mass was observed for sorghum plants grown in traditional spacing, with a population of 180 thousand plants ha 1, when compared to the spatial arrangement in double rows. On the other hand, in the experiment conducted in the second harvest of 2019, higher 
values of this response variable were found when sorghum was grown in populations greater than 300 thousand plants $\mathrm{ha}^{-1}$ in a double row arrangement, also showing, in the average of all of the populations evaluated, superiority of the double row arrangement over the traditional one.

Table 2. Average values of agronomic characteristics plant height, stem thickness, number of tiller and panice length grown in second crop in different spatial arrangements of plants.

\begin{tabular}{|c|c|c|c|c|c|c|}
\hline \multirow{2}{*}{ Plant population (x 1000) } & \multicolumn{3}{|c|}{2018} & \multicolumn{3}{|c|}{2019} \\
\hline & TDC & FLD & Mean & TDC & FLD & Mean \\
\hline & \multicolumn{6}{|c|}{ Plant height (m) } \\
\hline 120 & $1.19 \mathrm{a}$ & $1.18 \mathrm{a}$ & 1.19 & $1.33 \mathrm{a}$ & $1.34 \mathrm{a}$ & 1.34 \\
\hline 180 & $1.21 \mathrm{a}$ & $1.19 \mathrm{a}$ & 1.20 & $1.36 \mathrm{a}$ & $1.36 \mathrm{a}$ & 1.36 \\
\hline 240 & $1.12 \mathrm{~b}$ & $1.25 \mathrm{a}$ & 1.19 & $1.38 \mathrm{a}$ & $1.36 \mathrm{a}$ & 1.37 \\
\hline 300 & $1.21 \mathrm{a}$ & $1.25 \mathrm{a}$ & 1.23 & $1.40 \mathrm{a}$ & $1.42 \mathrm{a}$ & 1.41 \\
\hline 360 & $1.21 \mathrm{a}$ & $1.24 \mathrm{a}$ & 1.22 & $1.36 \mathrm{a}$ & $1.41 \mathrm{a}$ & 1.38 \\
\hline \multirow[t]{2}{*}{ Mean } & $1.19 \mathrm{~b}$ & $1.22 \mathrm{a}$ & & $1.37 \mathrm{a}$ & $1.38 \mathrm{a}$ & \\
\hline & \multicolumn{6}{|c|}{ Stem thickness (mm) } \\
\hline 120 & 13.02 & 14.52 & 13.77 & 19.60 & 18.80 & 19.20 \\
\hline 180 & 12.70 & 12.02 & 12.36 & 16.40 & 15.40 & 15.90 \\
\hline 240 & 11.02 & 11.72 & 11.37 & 15.70 & 14.70 & 15.20 \\
\hline 300 & 11.87 & 11.72 & 11.80 & 14.40 & 14.20 & 14.30 \\
\hline 360 & 10.67 & 10.60 & 10.64 & 13.80 & 13.50 & 13.65 \\
\hline \multirow[t]{2}{*}{ Mean } & $11.86 \mathrm{a}$ & $12.12 \mathrm{a}$ & & $15.98 \mathrm{a}$ & $15.32 \mathrm{a}$ & \\
\hline & \multicolumn{6}{|c|}{ Number of tillers } \\
\hline 120 & 0.75 & 1.00 & 0.87 & 0.00 & 0.00 & 0.00 \\
\hline 180 & 1.25 & 1.50 & 1.37 & 0.00 & 0.00 & 0.00 \\
\hline 240 & 0.75 & 1.75 & 1.25 & 0.00 & 0.00 & 0.00 \\
\hline 300 & 1.75 & 2.50 & 2.12 & 0.50 & 0.00 & 0.25 \\
\hline 360 & 3.50 & 2.75 & 3.12 & 0.00 & 0.00 & 0.00 \\
\hline \multirow[t]{2}{*}{ Mean } & $1.60 \mathrm{a}$ & $1.90 \mathrm{a}$ & & $0.10 \mathrm{a}$ & $0.00 \mathrm{a}$ & \\
\hline & \multicolumn{6}{|c|}{ Panicle length $(\mathrm{cm})$} \\
\hline 120 & 29.22 & 29.90 & 29.56 & 30.67 & 31.35 & 31.01 \\
\hline 180 & 28.17 & 26.95 & 27.56 & 29.32 & 29.12 & 29.22 \\
\hline 240 & 27.32 & 26.52 & 26.92 & 28.25 & 28.55 & 28.40 \\
\hline 300 & 27.30 & 26.77 & 27.03 & 27.85 & 28.52 & 28.19 \\
\hline 360 & 26.82 & 25.80 & 26.31 & 27.37 & 28.12 & 27.75 \\
\hline Mean & $27.77 \mathrm{a}$ & $27.19 \mathrm{a}$ & & $28.69 \mathrm{a}$ & $29.13 \mathrm{a}$ & \\
\hline
\end{tabular}

TDC: traditional spacing between rows $(0.5 \mathrm{~m})$; FDL: double rows spacing $(0.75 \mathrm{~m} / 0.25 \mathrm{~m})$. Means followed by the same letter do not differ significantly from each other by the $\mathrm{F}$ test $(\mathrm{p} \leq 0.05)$. 
In a similar way to that observed for the variable panicle mass, the behavior for the mass of a thousand grains was similar due to the spatial arrangement of plants in the two years in which the experiment was conducted (Table 3). In 2018, there was a superiority in the mass of a thousand grains of sorghum for plants grown in a traditional spatial arrangement, when the population adopted was 180 or 240 thousand plants $\mathrm{ha}^{-1}$. On the other hand, in the experiment conducted in 2019, the behavior of this response variable as a function of the spatial arrangements used was the opposite, since there was an increase in the final grain weight with the double row spacing, in populations of 300 and 360 thousand plants $\mathrm{ha}^{-1}$ and in the average of these, compared to the sowing carried out with $0.5 \mathrm{~m}$ between rows (traditional).

Table 3. Average values of the agronomic characteristics panicle mass, thousand grain mass and sorghum yield grown in second crop in different spatial arrangements of plants.

\begin{tabular}{|c|c|c|c|c|c|c|}
\hline \multirow{2}{*}{ Plant population (x 1000) } & \multicolumn{3}{|c|}{2018} & \multicolumn{3}{|c|}{2019} \\
\hline & TDC & FLD & Mean & TDC & FLD & Mean \\
\hline & \multicolumn{6}{|c|}{ Panicle mass $(\mathrm{g})$} \\
\hline 120 & 50.46 & 51.05 & 50.75 & 61.75 & 64.87 & 63.31 \\
\hline 180 & $49.85 \mathrm{a}$ & $35.81 \mathrm{~b}$ & 42.83 & $52.00 \mathrm{~b}$ & $61.97 \mathrm{a}$ & 56.98 \\
\hline 240 & 36.60 & 35.02 & 35.81 & 41.75 & 39.77 & 40.76 \\
\hline 300 & 33.94 & 33.82 & 33.88 & 33.75 & 38.75 & 36.25 \\
\hline 360 & 32.04 & 32.08 & 32.06 & 32.62 & 39.35 & 35.99 \\
\hline \multirow[t]{2}{*}{ Mean } & $40.58 \mathrm{a}$ & $37.55 \mathrm{a}$ & & $44.37 \mathrm{~b}$ & $48.94 \mathrm{a}$ & \\
\hline & \multicolumn{6}{|c|}{ Mass of thousand grains $(\mathrm{g})$} \\
\hline 120 & 17.88 & 18.74 & 18.31 & 26.48 & 25.47 & 25.97 \\
\hline 180 & $18.49 \mathrm{a}$ & $17.03 \mathrm{~b}$ & 17.76 & 22.74 & 23.79 & 23.27 \\
\hline 240 & $18.65 \mathrm{a}$ & $16.79 \mathrm{~b}$ & 17.72 & 23.21 & 23.43 & 23.32 \\
\hline 300 & 17.47 & 18.77 & 18.12 & $21.85 \mathrm{~b}$ & $24.41 \mathrm{a}$ & 23.13 \\
\hline 360 & 19.25 & 18.49 & 18.87 & $22.84 \mathrm{~b}$ & $25.44 \mathrm{a}$ & 24.14 \\
\hline \multirow{2}{*}{ Mean } & $18.35 \mathrm{a}$ & $17.96 \mathrm{a}$ & & $23.42 \mathrm{~b}$ & $24.51 \mathrm{a}$ & \\
\hline & \multicolumn{6}{|c|}{ Grain yield $\left(\mathrm{kg} \mathrm{ha}^{-1}\right)$} \\
\hline 120 & $4536.14 \mathrm{a}$ & $4364.07 \mathrm{a}$ & 4450.11 & $4940.22 \mathrm{a}$ & $5637.46 \mathrm{a}$ & 5288.84 \\
\hline 180 & $5007.94 \mathrm{a}$ & $3332.33 \mathrm{~b}$ & 4170.13 & $5149.41 \mathrm{a}$ & $5718.06 \mathrm{a}$ & 5433.74 \\
\hline 240 & $4676.13 \mathrm{a}$ & $3305.01 \mathrm{~b}$ & 3990.57 & $6021.01 \mathrm{a}$ & $5916.77 \mathrm{a}$ & 5968.89 \\
\hline 300 & $5640.62 \mathrm{a}$ & $4823.39 \mathrm{a}$ & 5232.00 & $5331.05 \mathrm{~b}$ & $6902.25 \mathrm{a}$ & 6116.65 \\
\hline 360 & $6152.52 \mathrm{a}$ & $4856.09 \mathrm{~b}$ & 5504.30 & $6825.57 \mathrm{a}$ & $6652.28 \mathrm{a}$ & 6738.93 \\
\hline Mean & $5202.67 \mathrm{a}$ & $4136.18 \mathrm{~b}$ & & $5653.45 \mathrm{~b}$ & $6165.36 \mathrm{a}$ & \\
\hline
\end{tabular}

TDC: traditional spacing between rows $(0.5 \mathrm{~m})$; FDL: double rows spacing $(0.75 \mathrm{~m} / 0.25 \mathrm{~m})$. Means followed by the same letter do not differ significantly from each other by the $F$ test $(\mathrm{p} \leq 0.05)$.

The variation in the behavior of sorghum due to the special arrangement of plants between the two years in which the experiment was carried out may be related to the volume of precipitation that occurred during the experimental period. In the first year (2018), the volume of rainfall corresponded to half of the total seen in 2019, in addition to a very uneven distribution during the sorghum cycle. For the purpose of exemplifying that which was mentioned in relation to water irregularity in 2018, sorghum plants were subject to the occurrence of two small drought periods, one lasting for 11 days and the other lasting for 30 days, in addition to the fact that there was no precipitation from May $20^{\text {th }}$ onwards. In situations where there is a limitation of a certain vital resource for plant development (example: water), the special arrangement in double rows can favor the occurrence of intraspecific competition, since the plants on one side of the row will be in close proximity to the neighboring row, spaced only $0.25 \mathrm{~m}$ apart, making the edaphic environment explored by the roots practically the same. This behavior ends up favoring competition for water, and losses in yield may be observed in years with limited resources (GALON et al., 2018).

Finally, the sorghum grain yield data followed the behavior of those obtained for the yield components analyzed, with differences in plant responses depending on the year in which the experiment was conducted (Table 3 ). In the harvest in which the lowest rainfall was recorded (2018), whenever there was a difference between the spatial arrangements of plants, sorghum showed greater yield when sown in the traditional arrangement compared to that of double rows. As previously highlighted, this behavior may be related to intraspecific competition for water, a resource that was limiting the development of culture in the first year of the experiment. On the other hand, in the experiment conducted in the second harvest of 2019 , when there was a satisfactory volume and 
distribution of rainfall throughout the crop development cycle, the arrangement in double rows provided an increase in yield when the population of 300 thousand plants $\mathrm{ha}^{-1}$ was adopted, as well as an increase in the average of all populations evaluated.

Taking into account the results of both experiments, and seeking to relate what could be indicated in practical terms, it can be said that it is best to sow seeds in a traditional special arrangement under adverse conditions of development for culture, using the $0.5 \mathrm{~m}$ spacing between rows. As an example, a producer who intends to cultivate sorghum as a second crop and who has lost the sowing season positioned in the zoning of agroclimatic risk, which indicates that the crop will be more exposed to a water deficit during its cycle, the recommendation is to adopt sowing with traditional spacing. Similarly, producers who have
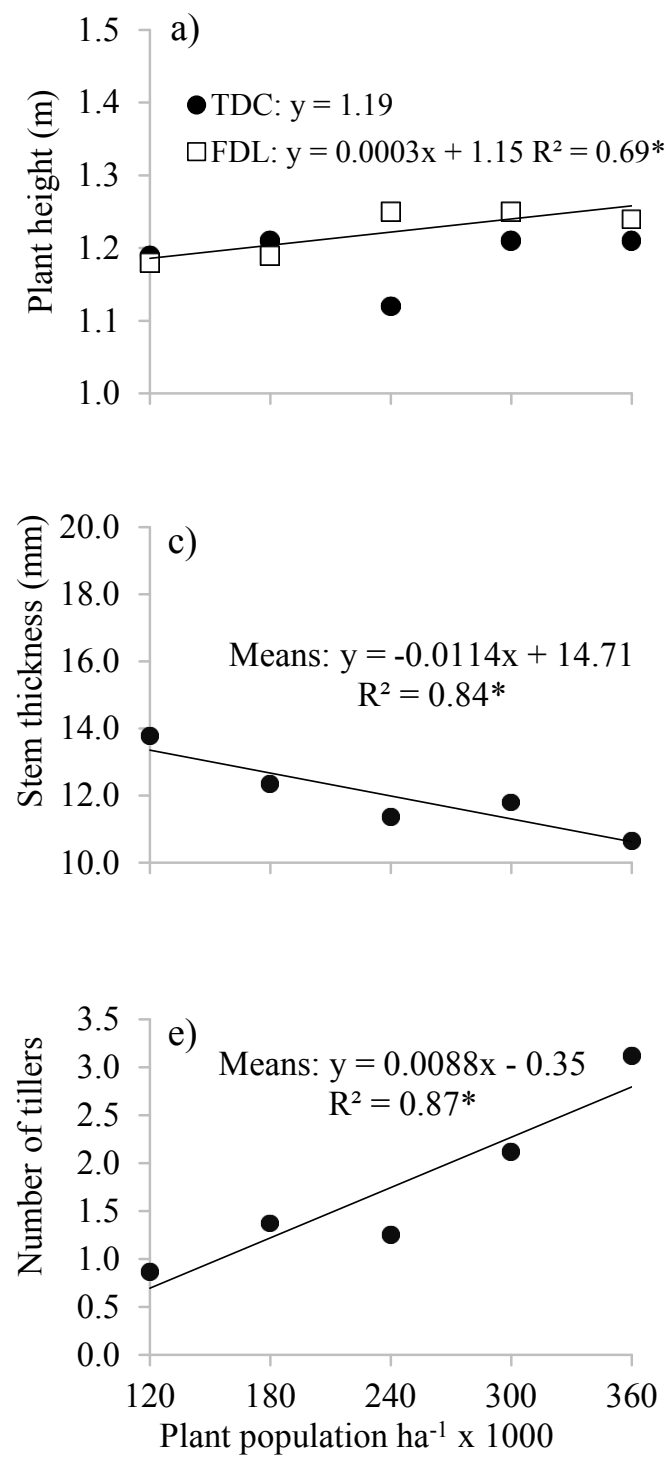

been programmed to sow in advance of the second harvest may adopt the spatial arrangement of double rows, since this provides an increase in sorghum yield in certain populations.

The results of height, stem thickness and number of sorghum tillers as a function of plant populations adopted in crop sowing, in both experiments, are shown in (Figure 2). For plant height, the effect of plant population on this variable was only observed when the spatial arrangement of double rows was adopted; this behavior was verified in the two years in which the experiment was carried out (Figures 2a and 2b). In the double row arrangement, positive linear behavior was observed in relation to the effect of the populations used on height, which indicates that with the increase in sorghum sowing density, there is an increase in plant height.
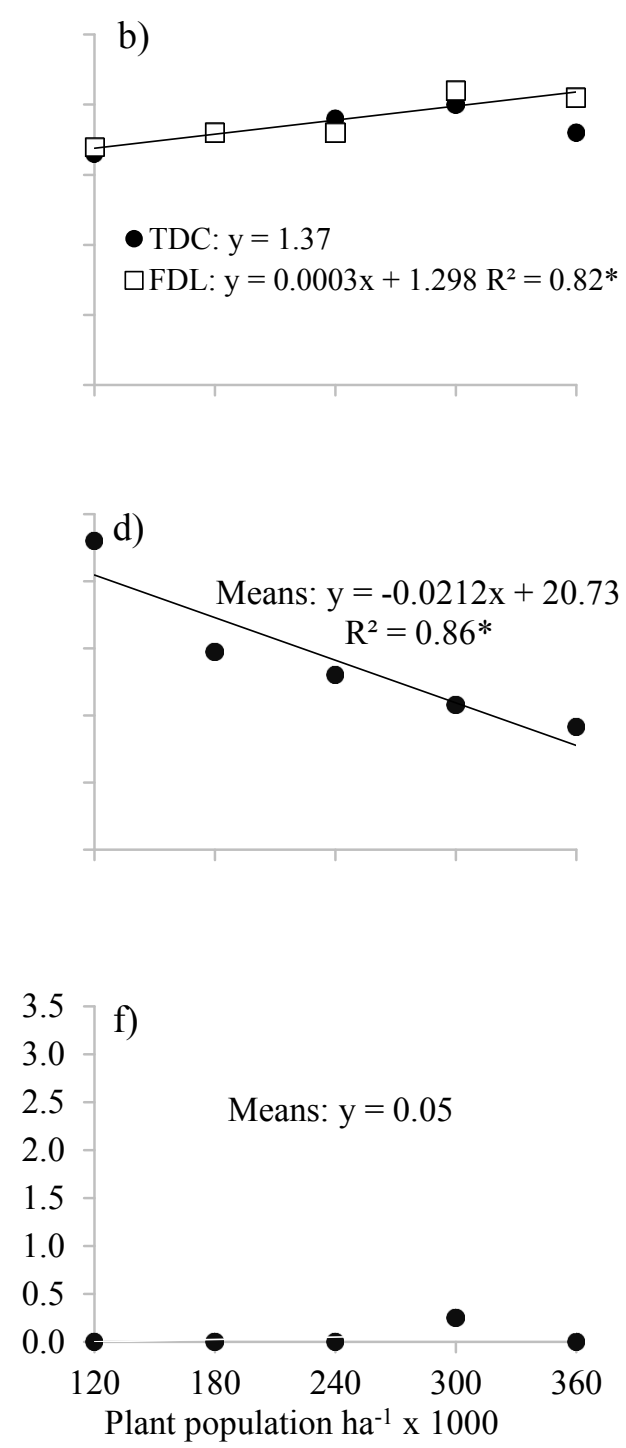

Figure 2. Plant height, stem thickness and number of sorghum tillers grown in second crop in different plant populations. Rio Verde (GO), 2018 (a, c, e) and 2019 (b, d, f). TDC: traditional spacing between rows $(0.5 \mathrm{~m})$; FDL: double rows spacing $(0.75 / 0.25 \mathrm{~m})$; Means: refers to the means between TDC and FDL. * Significant regression $(\mathrm{p} \leq 0.05)$.

Rev. Caatinga, Mossoró, v. 33, n. 2, p. 422 - 432, abr. - jun., 2020 
Regarding the effect of populations on the stalk thickness of sorghum plants, it appears that, regardless of whether the traditional or double row spatial arrangements were adopted, the behavior was similar, with a similarity also noted for this response variable between the years in which the experiment was conducted (Figures $2 \mathrm{c}$ and $2 \mathrm{~d}$ ). In this way, there was a tendency to decrease stalk thickness, as sowing was carried out with larger populations. These results indicate that the density of the crop in the sowing row may leave sorghum plants more exposed to lodging, since there is a decrease in stem diameter. Despite this, it is important to take into account the genetics of the material used, since sorghum breeding companies have been looking for cultivars with shorter stature and greater stiffness in the last decades (ROCHA JR. et al., 2000). For these materials, it is possible to work with higher sowing densities per meter of furrow.

The number of tillers was influenced by the increase in the population of sorghum plants only in the 2018 harvest, with a similar behavior being observed between the spatial arrangements used in sowing the crop (Figures $2 \mathrm{e}$ and $2 \mathrm{f}$ ). In the experiment in which the population influenced the tillering of the crop, an increase in the number of tillers was observed with an increase in sowing density. Studies previously presented in the literature demonstrate a tendency of behavior opposite to that registered in the present experiment (MONTAGNER et al., 2004; ALBUQUERQUE et al., 2011), since there was a reduction in the sorghum tillering with an increase in the population of plants $\mathrm{ha}^{-1}$. Despite this differentiation mentioned in the results, it is worth noting that the genetics of the cultivar used in the implantation is the main parameter that governs the crop's profiling capacity (ALBUQUERQUE et al., 2011), which may explain the behavior seen in the present experiment.

Figure 3 shows the results of panicle length and mass, thousand grain mass and sorghum grain yield as a function of spatial arrangements and plant population, in the two years in which the experiment was conducted. For the variables related to the measurements made on the panicle (length and mass), there is a tendency to decrease their absolute values as there is an increase in the population of sorghum plants (Figures 3a, 3b, 3c and 3d). This demonstrates that, because there is intraspecific competition for resources of the environment, sorghum plants end up presenting limitations in the development of reproductive structures. Depending on the intensity of reduction in the variables related to panicles, the compensatory effect provided by the increase in the plant population may not be enough to avoid losses in the final yield of the sorghum culture. In this way, when opting for denser crops, it is essential to make adjustments in the nutrition of the culture, and pay attention to the choice of the cultivar to be explored, as well as respecting the ideal sowing time. These results corroborate those observed by Albuquerque et al. (2011), in which, unlike in corn, one of the forms of compensation of sorghum to the smaller plant population is related to the increase in panicle mass.

The mass of a thousand grains was influenced by the adoption of different spatial arrangements in plants and populations used in the sowing of sorghum, with this behavior being observed in both years in which the experiment was carried out (Figures 3e and 3f). In 2018, there was only an effect of plant populations on the analyzed variable when the sorghum was sown in the spacing of double rows. On this occasion, the behavior was quadratic, with the lowest mass of a thousand grains in the population of 231.5 thousand plants ha ${ }^{-1}$. In spite of this, when observing the angle of the curve adjusted in the model, the small contribution that the increase in plant population has on the mass of a thousand grains is evident.

On the other hand, in the second experimental year (2019), in addition to checking the quadratic behavior for the double row arrangement again, there was an adjustment of this model for sorghum grown with $0.5 \mathrm{~m}$ spacing between rows (traditional) when the mass of a thousand grains was evaluated. It is noteworthy that, in the traditional arrangement, none of the populations within the evaluated range was able to provide a thousand grain mass greater than the lower density of the sown sorghum crop (120 thousand plants $\mathrm{ha}^{-1}$ ). Comparing the behavior of the results of the mass of a thousand grains between the two spatial arrangements evaluated, it appears that from populations of 180 thousand plants $\mathrm{ha}^{-1}$, the arrangement in double rows always presented a higher value of this variable in relation to the sorghum grown in traditional spacing.

Finally, for grain yield there is variation in the results between the two harvests in which the experiment was conducted, since the highest yields in 2018 were obtained with sorghum grown in traditional spacing, and the arrangement in double rows stood out in 2019, presenting higher production values (Figure $3 \mathrm{~g}$ and $3 \mathrm{~h}$ ). As previously discussed, the main factor that may explain this variation is related to the rainfall distribution between agricultural years, in which years with the occurrence of droughts, it is interesting to explore sorghum using $0.5 \mathrm{~m}$ between row. On the other hand, when good water distribution is forecast throughout the off-season, and the sowing is positioned within the ideal period, the use of the arrangement in double rows can contribute to greater yield. 

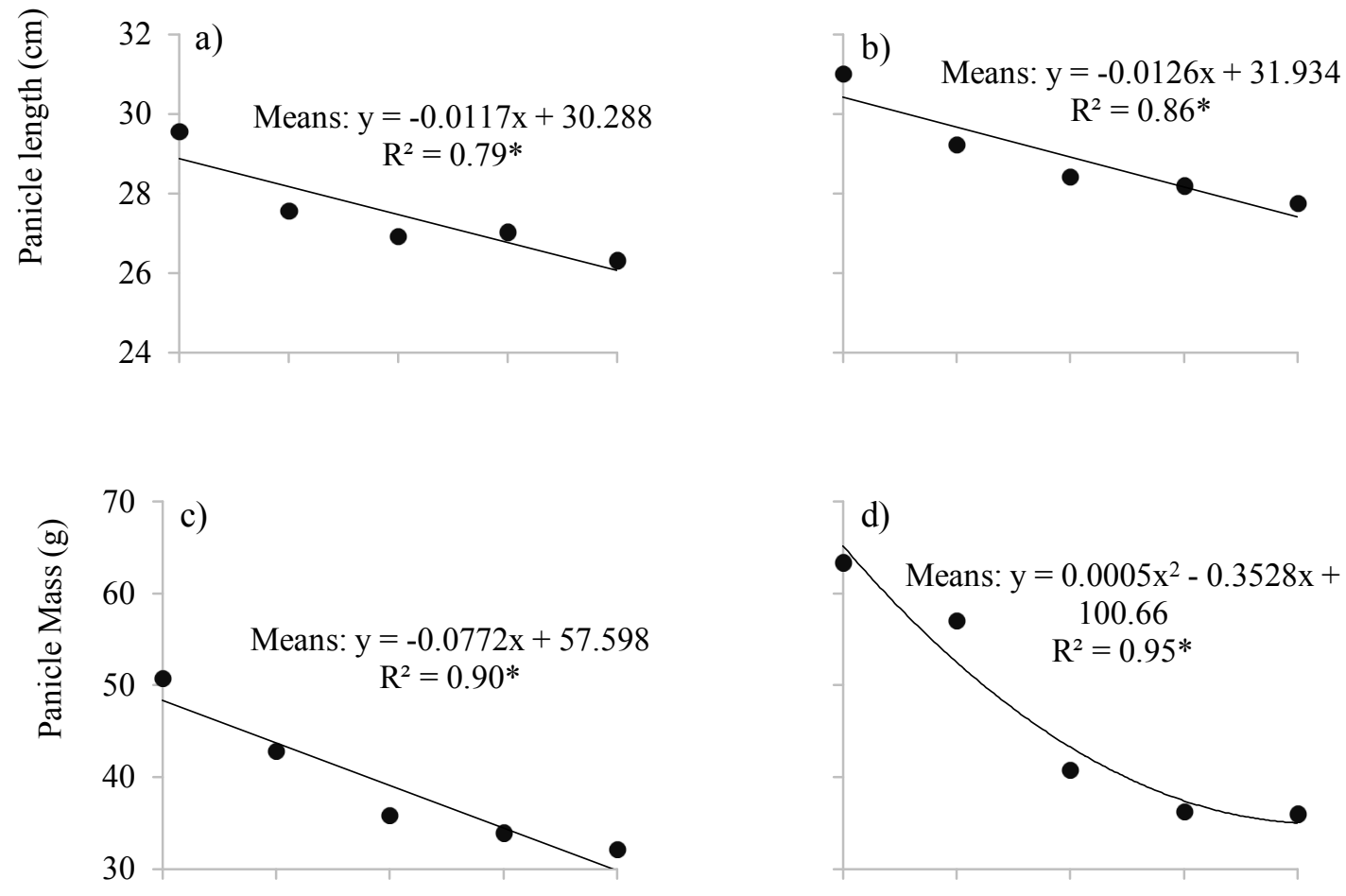

d)
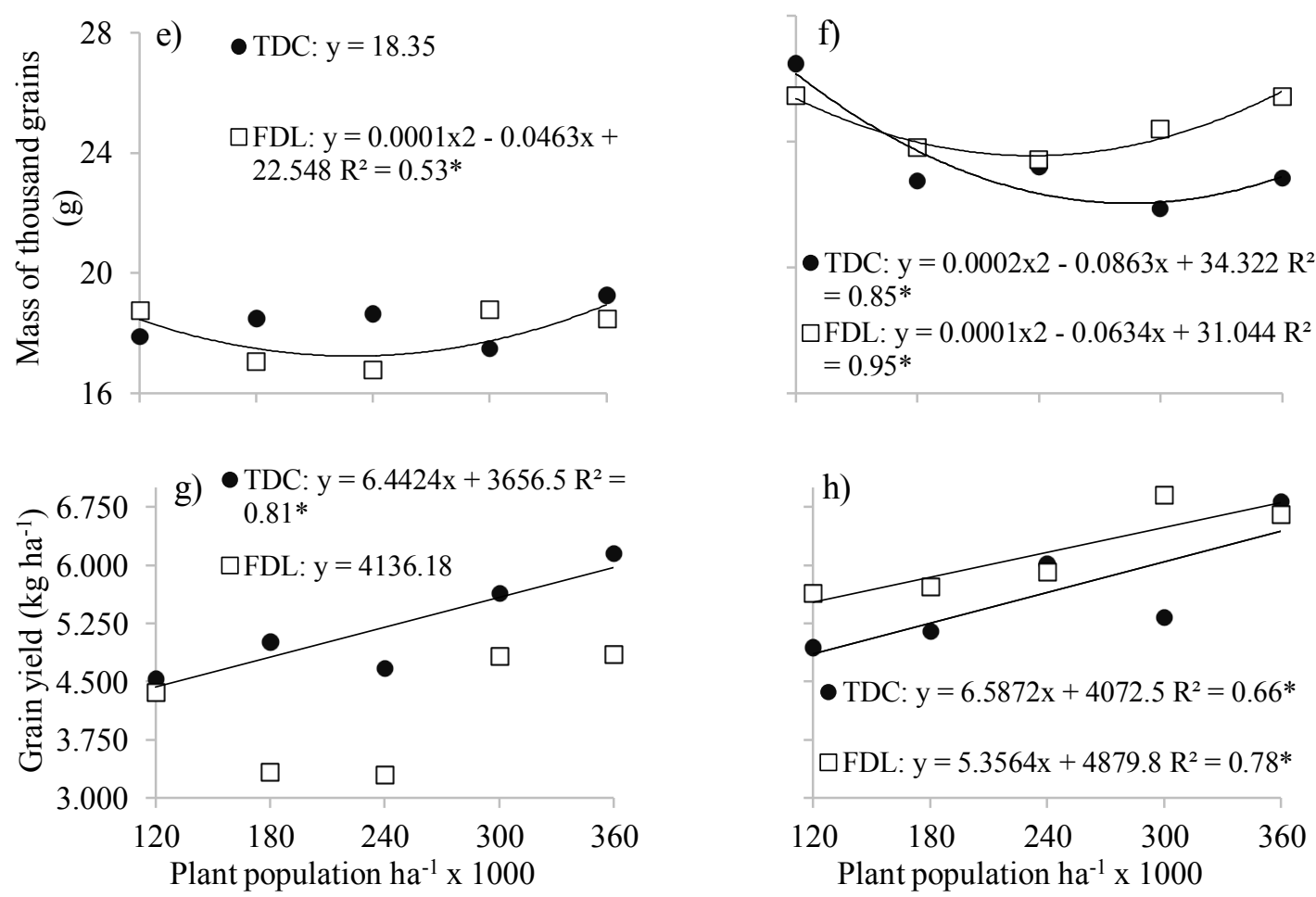

Figure 3. Panicle length and mass, thousand grain mass and grain yield of sorghum grown in second crop in different plant populations. Rio Verde (GO), 2018 (a, c, e, g) and 2019 (b, d, f, h). TDC: traditional spacing between rows (0.5 m); FDL: double rows spacing $(0.75 / 0.25 \mathrm{~m})$; Means: refers to the average between TDC and FDL. ${ }^{*}$ Significant regression $(\mathrm{p} \leq 0.05)$.

Regarding the increase in plant population, it appears that the response in the traditional arrangement is linear in 2018, with an average increase of one bag ha ${ }^{-1}\left(\cong \square 60 \mathrm{~kg} \mathrm{ha}^{-1}\right)$ for every 10,000 plants added per hectare. In the largest population of plants evaluated (360 thousand plants $\mathrm{ha}^{-1)}$, there was an increase of $24.07 \%$ in relation to the population positioned for most sorghum cultivars (180 thousand plants $\mathrm{ha}^{-1}$ ). This demonstrates that finding the balance between the price of seed acquisition and the increase in the population of sorghum plants, there is economic viability for the 
practice of population densification in this crop. Another benefit that can be obtained with the population density in sorghum refers to the cultural control of weeds (BRAZ et al., 2019), since closing earlier can reduce weed density, as well as decrease the allocation of dry matter, facilitating the management of the weed community.

In the 2018 harvest, there was no adjustment in the equation for the spatial arrangement in double rows with respect to the effect of plant population and sorghum yield. Nevertheless, when looking at the yield results in (Table 3), it appears that the sorghum showed an average yield of $1500 \mathrm{~kg} \mathrm{ha}^{-1}$ higher in the populations of 300 and 360 thousand plants $\mathrm{ha}^{-1}$, than in the populations of 180 and 240 thousand plants $\mathrm{ha}^{-1}$.

In the 2019 harvest, in both spatial arrangements, as the crop became denser in the sowing row, there was an increase in grain yield. When comparing the angular coefficient of the adjusted models, it appears that, although the superiority of the double row arrangement for yield was verified in the range of plant populations evaluated, in terms of an increase, the traditional arrangement was more responsive, since over 910 plants per $\mathrm{ha}^{-1}$ are required to increase yield by a bag $\mathrm{ha}^{-1}$ when sorghum is grown with a row space of $0.5 \mathrm{~m}$, while about 1.12 hectares plants $^{-1}$ are required for the arrangement in double rows.

\section{CONCLUSIONS}

Climatic conditions influence the behavior of the sorghum crop when changes are made in the spatial arrangement of plants, especially in harvests where there are irregularities in the distribution and volume of precipitation.

In adverse climatic conditions (small droughts), the use of the arrangement in double rows does not provide increases in the yield of sorghum grains when compared to the traditional spacing ( $0.5 \mathrm{~m}$ between rows). On the other hand, in years with good water distribution, the use of the double row arrangement brings gains in production.

Finally, it appears that the increase in plant population $\mathrm{ha}^{-1}$ provides an increase in the grain yield.

\section{ACKNOWLEDGEMENTS}

The University of Rio Verde - UniRV for making financial resources available for carrying out the research through a project approved in the Call for Scientific Research Grant of the referred institution.

\section{REFERENCES}

ALBUQUERQUE, C. J. B. et al. Espaçamento e densidade de semeadura para cultivares de sorgo granífero no semiárido. Bragantia, 70: 278-285, 2011.

ALBUQUERQUE, C. J. B. et al. Reduced spacing for Sorghum bicolor in the irrigated and rainfed systems. Pesquisa Aplicada \& Agrotecnologia, 3: 7 $-16,2010$.

ALMEIDA, M. L. et al. Incremento na densidade de plantas: uma alternativa para aumentar o rendimento de grãos de milho em regiões de curta estação estival de crescimento. Ciência Rural, 30: 23-29, 2000.

AVELINO, P. M. et al. Características agronômicas e estruturais de híbridos de sorgo em função de diferentes densidades de plantio. Revista Ciência Agronômica, 42: 534-541, 2011.

BAUMHARDT, R. L., HOWELL, T. A. Seeding Practices, Cultivar maturity, and irrigation effects on simulated grain sorghum yield. Agronomy Journal, 98: 462-470, 2006

BENEDETTI, P. et al. Influência do nitrogênio na cultura do sorgo BRS 506 para a produção de biomassa. Ciência \& Tecnologia, 7: 131-135, 2015.

BRAZ, G. B. P. et al. Desempenho agronômico e supressão de plantas daninhas no sorgo em semeadura adensada. Revista de Ciências Agroveterinárias, 18: 170-177, 2019.

BUFFARA, M. A. et al. Seeding system and density for winter Urochloa ruziziensis intercropped with sorghum between soybean crops. Comunicata Scientiae, 9: 340-350, 2018.

FERNANDES, P. G. et al. Influência do espaçamento e da população de plantas de sorgo sacarino em diferentes épocas semeadura. Ciência Rural, 44: 975-981, 2014

FERREIRA, D. F. Sisvar: a computer statistical analysis system. Ciência e Agrotecnologia, 35: 1039-1042, 2011.

GALON, L. et al. Competitive interaction between sweet sorghum with weeds. Planta Daninha, 36 e018173689, 2018.

INSTITUTO BRASILEIRO DE GEOGRAFIA E ESTATÍSTICA - IBGE. Levantamento sistemático de produção agrícola. Available in: https:// sidra.ibge.gov.br/tabela/1618. Acessed in: Oct. 24, 
2019.

KASPARY, T. E. et al. Regulador de crescimento na produtividade e qualidade de sementes de aveiabranca. Planta Daninha, 33: 739-750, 2015.

MAGALHÃES, P. C. et al. Fisiologia da planta de sorgo. 3. ed. Sete Lagoas, MG: Embrapa Milho e Sorgo, 2000. 46 p.

MONTAGNER, D. et al. Perdas aleatórias na população inicial e sua relação com o rendimento de grãos em sorgo. Current Agricultural Science and Technology, 10: 281-285, 2004.

PENCKOWSKI, L. H. et al. Nitrogênio e redutor de crescimento em trigo de alta produtividade. Acta Scientiarum. Agronomy, 31: 473-479, 2009.

PINHO, G. V. R.; VASCONCELOS, R. C. Cultura do sorgo. 1. ed. Lavras, MG: Editora UFLA FAEPE, 2002. 76 p.

ROCHA JR., V. R. et al. Avaliação de sete genótipos de sorgo (Sorghum bicolor (L.) Moench) para produção de silagem. I - Características agronômicas. Arquivo Brasileiro de Medicina Veterinária e Zootecnia, 52: 506-511, 2000.

SANTOS, H. G. et al. Sistema brasileiro de classificação de solos. 5. ed. Rio de Janeiro: Embrapa Solos, 2018. 306 p.

WEATHERBASE. Rio Verde, Goiás, 2019. Available in: <https://www.weatherbase.com/ weather/weather.php3?s=597703\&cityname=RioVerde-Goias-Brazil>. Acessed in: Oct. 19, 2019. 